\title{
Enfermedad de motoneurona asociada a procesos neoplásicos: una revisión de casos
}

Motor Neuron Disease associated with a neoplastic procesess: a review of cases

\author{
Raquel Rocha, Luis Ribeiro, Filipe Correia, Andreia Santos, João Martins \\ Hospital Pedro Hispano, Unidade Local de Saúde de Matosinhos
}

\begin{abstract}
Introduction: Association between Motor Neuron Disease (MND) and neoplastic processes is rarely described. It is unclear whether MND occurs as a paraneoplastic syndrome.

Methods: We retrospectively analysed 35 patients with MND followed in our Hospital from January 2013 to December 2016. Results: A neoplastic process was found in four patients. All of them had definite clinical and electromyographic criteria supporting MND according to standard Awaji criteria. Results: Onconeuronal antibodies were positive in two patients (anti-Yo and anti-PNMA2). The types of tumour were variable: two breast cancers, one lung cancer and one thyroid Hürthle cell neoplasm. Discussion: In our cohort, $11.4 \%$ of MND patients were diagnosed with a neoplastic process being a rather high frequency of co-occurrence. Treating the neoplastic process may potentially halt or reverse the progression of MND.
\end{abstract}

Keywords: Motor Neuron Disease; Neoplastic process; Paraneoplastic neurological disorders.

\section{INTRODUCTION}

Paraneoplastic Neurological Disorders (PNDs) are remote effects of systemic malignancies that affect the nervous system ${ }^{1,2}$. PNDs are relatively rare compared to metastatic and iatrogenic complications of cancer, and overall affect fewer than $1 \%$ of patients with cancer ${ }^{3}$. The most common neoplasms associated with paraneoplastic neurological disorders are small cell lung cancer, breast and gynaecological cancers, and lymphoma ${ }^{1,3,4}$.

Association between Motor Neuron Disease (MND) and neoplastic processes is rarely described ${ }^{4-6}$. Cases of paraneoplastic MND are rarely observed and, as a result, no exhaustive data are available on the exact clinical and neurophysiological phenotype associated with this condition ${ }^{6}$. part of Springer Nature Paraneoplastic motor neuron disorders (MND). It is currently unclear whether MND even occurs as a paraneoplastic syndrome. Many authors have questioned whether the association of cancer and MND is simply a coincidence of two relatively common diseases, or if there is a true etiologic relationship ${ }^{3,6,7}$. Some small studies have reported a co-occurrence of cancer and MND that appears to be higher than the incidence expected in the general population ${ }^{7}$ and few reports addressed the possibility of MND reversal after treatment of a coexistent neoplasm ${ }^{8-10}$.

In patients with an acute to subacute onset of neuromuscular symptoms without a known tumour, the etiology may be paraneoplastic when there is a well known syndrome presented by the patient or if there is a specific anti-neuronal antibody such as anti-Yo or anti-PNMA2, in serum or cerebrospinal fluid ${ }^{1,6}$.
Here, we present four patients with MND and a coexistent neoplasm.

\section{OBJECTIVES}

1) To do a retrospective analysis of all patients with MND in our cohort who had an associated tumour.

2) Verify if there is any correlation between treatment of the underlying tumour and improvement of MND in those patients.

\section{METHODS}

We analysed through a 4-year retrospective study, from January 2013 to December 2016, the files of patients with an active MND (of every subtype) in our Hospital $(\mathrm{N}=35)$. The hospital total referral population is 315000 inhabitants. There was no need of approval of ethic committee due to being a retrospective study and no intervention was made. Clinical and electrophysiological examination (EMG) was performed in all patients. Awaji criteria ${ }^{11}$ were applied for Clinical and Electrophysiological diagnosis of MND.

An active search for a primitive tumour was made as part of the investigation for treatable causes of MND, according to EFNS 2012 Guidelines $^{12}$.

\section{CASES REPORT/RESULTS}

A neoplastic process was found in four $(11,4 \%)$ of our MND patients (table 1).

Case 1 is a 55 -year-old female, refered for breast tumorectomy and radiotherapy in 2005 due to invasive ductal breast cancer (IDBC), which was BRCA2 mutation-related. The IDBC 
Table 1. Summary of the 4 patients of MND with an associated neoplastic process.

\begin{tabular}{|c|c|c|c|c|}
\hline & Case 1 & Case 2 & Case 3 & Case 4 \\
\hline Sex & $\mathrm{F}$ & M & $\mathrm{F}$ & M \\
\hline Age & 55 & 48 & 74 & 77 \\
\hline Neoplasm type & $\begin{array}{l}\text { Invasive ductal breast Ca } \\
\text { (BRCA2 mutation-related) }\end{array}$ & $\begin{array}{l}\text { Imaging: 8mm thyroid nodule } \\
\text { Histology: Hürthle cell folicular } \\
\text { thyroid tumour }\end{array}$ & Invasive ductal breast $\mathrm{Ca}$ & Lung adenocarci-noma \\
\hline $\begin{array}{c}\text { Time between neoplasm } \\
\text { identification and MND } \\
\text { diagnosis }\end{array}$ & $\begin{array}{l}\text { Breast Ca 2005. Relapsed in } \\
\text { December of 2015; MND in } \\
\text { early } 2016\end{array}$ & $\begin{array}{l}1^{\text {st }} \text { MND dx in September } 2015 . \\
\text { Thyroid tumour } d x \text { in October } \\
\text { of } 2016\end{array}$ & $\begin{array}{c}\text { Breast Ca in } 2014 . \\
\text { MND in January of } 2016\end{array}$ & $\begin{array}{l}1^{\text {st }} \text { MND dx in } 2010 . \\
\text { Lung Ca dx in } 2011\end{array}$ \\
\hline Onconeural antibodies & Anti-PNMA2 weakly positive & $\begin{array}{c}\text { Anti-Yo positive } \\
\text { (in two separated samples) }\end{array}$ & Not performed & Not performed \\
\hline $\begin{array}{c}\text { Topography of MND } \\
\text { involvement }\end{array}$ & $\begin{array}{l}\mathrm{U}+\mathrm{L} \text { MND, } \mathrm{B}+\mathrm{C}+\mathrm{D}+\mathrm{LS} \\
\text { segments }\end{array}$ & L MND, B+C+D+LS segments & $\begin{array}{l}\mathrm{U}+\mathrm{L} \text { MND, } \mathrm{B}+\mathrm{C}+\mathrm{D}+\mathrm{LS} \\
\text { segments }\end{array}$ & $\begin{array}{c}\mathrm{U}+\mathrm{L} \text { MND, } \mathrm{B}+\mathrm{C}+\mathrm{D}+\mathrm{LS} \\
\text { segments }\end{array}$ \\
\hline Neoplasm treatment & Sx, HT & $\begin{array}{c}\text { Sx - } \\
\text { Hemithyroidectomy }\end{array}$ & Sx, RT, HT & Sx, CT, RT \\
\hline IT & -- & IVlg - 2 cycles & -- & -- \\
\hline Evolution and Follow-up & $\begin{array}{l}\text { Aggressive with severe bulbar } \\
\text { impairment } \\
\text { Follow-up in palliative care }\end{array}$ & $\begin{array}{l}\text { Aggressive evolution, patient } \\
\text { refused total thyroidectomy }\end{array}$ & $\begin{array}{l}\text { Aggressive evolution. } \\
\text { Death in } 2017\end{array}$ & $\begin{array}{c}\text { Slowly progressive MND. } \\
\text { Death in } 2016\end{array}$ \\
\hline
\end{tabular}

relapsed in December 2015 leading to bilateral mastectomy and hormone therapy (the patient refused chemotherapy). After one month, the patient developed symptoms of upper and lower $(\mathrm{U}+\mathrm{L}) \mathrm{MND}$ affecting bulbar, cervical, dorsal and lumbosacral $(B+C+D+L S)$ segments. Onconeuronal antibodies were weakly positive for anti-PNMA2 detected by immunoblotting. The course was very aggressive and in one year she developed severe functional impairment and died.

Case 2 is a 48-year-old male developing lower MND signs affecting $\mathrm{B}+\mathrm{C}+\mathrm{D}+\mathrm{LS}$ segments starting in September 2015 and progressing very rapidly. Onconeural antibodies were positive in two different samples for anti-Yo by immunoblotting. He had one $8 \mathrm{~mm}$ thyroid nodule, and a Hürthle cell follicular thyroid tumour was diagnosed in October 2016. The patient was submitted to hemithyroidectomy in November 2016 followed by two cycles of IVIg. He didn't significantly progress in the subsequent 8 months of these treatments but recently, after a period of stable plateau, the MND aggressively worsened again and anti- $Y_{0}$ remained positive. He was referred for total thyroidectomy but refused another surgical procedure.

Case 3 is a 74-year-old female diagnosed with IDBC in 2014, submitted to mastectomy, radiotherapy and hormone therapy. In January of 2016, the patient developed symptoms of $\mathrm{U}+\mathrm{L}$ MND affecting $\mathrm{B}+\mathrm{C}+\mathrm{D}+\mathrm{LS}$ segments, progressing rapidly. Onconeural antibody analysis wasn't performed. She died in February 2017.

Case 4 is a 77-year-old male who presented with $U+L$ MND affecting $\mathrm{B}+\mathrm{C}+\mathrm{D}+\mathrm{LS}$, in 2010 . He was diagnosed with lung adenocarcinoma in 2011 and prescribed chemotherapy and radiotherapy. He died in January 2016. Onconeural antibody analysis wasn't performed.

\section{DISCUSSION}

In our cohort of only 35 MND patients, we identified four that had a coexistent neoplasm. This frequency of cooccurrence is higher than the relatively few previous reports $6,8,9,10,13,14$. In one of the four patients (case 2), the initially aggressive MND process became relatively stable, with a plateau phase through 8 months, after hemithyroidectomy followed by therapy with two cycles of IVIg, but progressed aggressively thereafter, and patient refused total thyroidectomy. However this suggests a physiological connection between the MND and neoplasm in this case. The other three patients died, two of them very rapidly due to the aggressiveness of the disease. This ferocious course of the disease, and the relative frequency, strongly supports a recommendation for physicians to for an underlying neoplasm as standard.

MND as a paraneoplastic process is a difficult diagnosis to establish with certainty ${ }^{13}$. The coexistence may be circumstantial. Reports of patients with typical MND who had improvement following treatment of their malignancy suggest that MND could occur as a paraneoplastic phenomenon ${ }^{14}$. Unfortunately, most paraneoplastic motor disorders are unresponsive to treatment of the underlying tumour $^{4}$. To complicate matters, MND may evolve aggressively and death can occur before the identification of an underlying causal neoplasm. In all the literature there are rather too few such cases with disparate antibodies, clinical courses, and underlying tumours to make further generalizations.

\section{CONCLUSIONS}


Even though paraneoplastic MND is rare, it's recognition is essential, because early management with immunotherapy and cancer treatment can lead to neurological improvement or stabilization ${ }^{6,9}$. This report is relevant to raise awareness of the importance of appropriate and thorough investigation for treatable causes of MND.

\section{BIBLIOGRAPHY}

1. Katirji B, Kaminkski H, Ruff RL. Neuromuscular Disorders in Clinical Practice. Springer Science \& Business Media. 2013.

2. Grisold W, Grisold A. Neuromuscular complications in cancer. J Neurol Sci. 2016;367(2016):184-202.

3. Rees JH. Paraneoplastic syndromes: when to suspect, how to confirm, and how to manage. J Neurol Neurosurg Psychiatry. 2004;75 Suppl 2:ii43-50.

4. Fearon C, Murray B, Mitsumoto H. Disorders of Upper and Lower Motor Neurons. In: Bradley's Neurology in Clinical Practice. Elsevier; 2016.

5. Corcia P, Gordon PH, Camdessanche J-P. Is there a paraneoplastic ALS? Amyotroph Lateral Scler Front Degener. 2015;16.

6. Mélé N, Berzero G, Maisonobe T, Salachas F, Nicolas G, Weiss N, et al. Motor neuron disease of paraneoplastic origin: a rare but treatable condition. J Neurol. 2018;265(7):1590-9.

7. David C., Preston MD BES. Atypical Motor Neuron Disorders. In: Electromyography and Neuromuscular Disorders. 3rd editio. 2013. p. 432-47.

8. Verschueren A, Gallard J, Boucraut J, Honnorat J, Pouget J, Attarian S. Paraneoplastic subacute lower motor neuron syndrome associated with solid cancer. J Neurol Sci. 2015;358(1-2):413-6.
9. Mehrpour M, Mohebi N, Motamed MR, Zamani F. Amyotrophic lateral sclerosis as a paraneoplastic manifestation in the neuroendocrine tumor of stomach: A case report. Acta Med Iran. 2013;51(10):724-6.

10. Turk HM, Ozet A, Kuzhan O, Komurcu F, Arpaci F, Ozturk B, et al. Paraneoplastic motor neuron disease resembling amyotrophic lateral sclerosis in a patient with renal cell carcinoma. Med Princ Pract. 2009;18(1):73-5.

11. Costa J, Swash M, de Carvalho M. Awaji Criteria for the Diagnosis of Amyotrophic Lateral Sclerosis. Arch Neurol. 2012;69(11):1410.

12. Andersen PM, Abrahams S, Borasio GD, de Carvalho M, Chio A, Van Damme P, et al. EFNS guidelines on the Clinical Management of Amyotrophic Lateral Sclerosis (MALS) - revised report of an EFNS task force. Eur J Neurol. 2012;19(3):360-75.

13. Pillainayagam C, Mella D, Johnson J, Woodman K. Unusual case of motor neuron disease as a paraneoplastic process (P4.230). Neurol. 2015 Apr 6;84(14 Supplement).

14. Diard-Detoeuf C, Dangoumau A, Limousin N, Biberon J, Vourc'H P, Andres CR, et al. Association of a paraneoplastic motor neuron disease with anti-Ri antibodies and a novel SOD1 I18del mutation. J Neurol Sci. 2014;337(1-2):212-4. 